\title{
Gut microbiota, probiotics and diabetes
}

\author{
Aline Corado Gomes ${ }^{1}$, Allain Amador Bueno², Rávila Graziany Machado de Souza ${ }^{1}$ and João Felipe Mota ${ }^{\text {* }}$
}

\begin{abstract}
Diabetes is a condition of multifactorial origin, involving several molecular mechanisms related to the intestinal microbiota for its development. In type 2 diabetes, receptor activation and recognition by microorganisms from the intestinal lumen may trigger inflammatory responses, inducing the phosphorylation of serine residues in insulin receptor substrate-1, reducing insulin sensitivity. In type 1 diabetes, the lowered expression of adhesion proteins within the intestinal epithelium favours a greater immune response that may result in destruction of pancreatic $\beta$ cells by CD8+ T-lymphocytes, and increased expression of interleukin-17, related to autoimmunity. Research in animal models and humans has hypothesized whether the administration of probiotics may improve the prognosis of diabetes through modulation of gut microbiota. We have shown in this review that a large body of evidence suggests probiotics reduce the inflammatory response and oxidative stress, as well as increase the expression of adhesion proteins within the intestinal epithelium, reducing intestinal permeability. Such effects increase insulin sensitivity and reduce autoimmune response. However, further investigations are required to clarify whether the administration of probiotics can be efficiently used for the prevention and management of diabetes.
\end{abstract}

Keywords: Probiotics, Diabetes mellitus, Gut microbiota, Inflammation, Insulin resistance

\section{Introduction}

According to the World Health Organization [1], the global prevalence of diabetes is approximately $10 \%$, reaching up to $33 \%$ of the population in some regions. Diabetes is a condition of multifactorial origin, including genetic and environmental factors, and accounts for 3.5\% of the mortality cases due to non-communicable chronic diseases. Scientific evidence suggests increased inflammatory stress is related to molecular mechanisms leading to insulin resistance, and the intestinal microbiota interacts with environmental factors and susceptible genetic factors, contributing to the development of diabetes [2].

The human gastrointestinal tract contains in average $10^{14}$ microorganisms $/ \mathrm{ml}$ of luminal content, and features over 5000 bacterial species. Among bacterial species, approximately $90 \%$ of them belong to the Bacteroidetes phyla, composed mainly of Gram- bacteria, and the Firmicutes phyla, composed mainly of Gram + bacteria. It has been suggested that the intestinal microbiota composition is associated with conditions such as allergies, intestinal inflammatory diseases, cancer, diabetes,

\footnotetext{
* Correspondence: jfemota@gmail.com

'Laboratório de Investigação em Nutrição Clínica e Esportiva (Labince). Faculdade de Nutrição, Universidade Federal de Goiás, Rua 227 Qd. 68s/no Setor Leste Universitário, Goiânia, Goiás, Brazil

Full list of author information is available at the end of the article
}

cardiovascular diseases and dyslipidaemia [3,4]. It has also been suggested that altered intestinal microbiota leads to increased intestinal permeability and mucosal immune response, contributing to the development of diabetes. Increased intestinal permeability is a result of reduced expression of tight junction proteins, eventually favouring the translocation of bacterial lipopolysaccharide (LPS), which may result in metabolic endotoxemia and insulin resistance $[5,6]$.

Modulation of intestinal microbiota by probiotics may facilitate the management of a number of clinical conditions [7]. Probiotics may be involved in the maintenance of a healthier gut microbiota, and have also been identified as effective adjuvants in insulin resistance therapies [8-10]. Hence, this systematic review appraises the current literature covering gut microbiota, probiotics and diabetes. Our aim is to clarify the currently described effects of probiotics in the prevention and management of type 1 (T1D) and type 2 (T2D) diabetes mellitus.

\section{Methods}

A systematic literature review has been performed over the electronic databases Medline PubMed and SciELO (The Scientific Electronic Library Online). The reference list of identified articles has also been reviewed. For this 
search, the following descriptors were considered: "diabetes," "oxidative stress", "probiotics", "inflammation", "insulin" and "microbiota". The logical connectives "and", "or" and "and not" were systematically used to combine descriptors and terms used to trace the publications.

As a result of this appraisal conducted in December 2013, 287 publications were identified. Subsequently, the articles that met the following inclusion criteria were selected: (a) experimental studies that investigated assessment of insulin sensitivity, glucose tolerance test, intestinal permeability and or markers of oxidative stress and inflammation; (b) literature review articles; (c) articles preferably published after 2002 .

After reconsideration based on the inclusion criteria, 166 articles were excluded for one of the two following reasons: the effects of probiotics were related to other pathologies other than diabetes; or, probiotics were not the main objective of the study. Therefore, 121 articles met all the inclusion criteria and were reviewed.

\section{Intestinal microbiota and type $\mathbf{2}$ diabetes}

Muscle and adipose tissue resistance to insulin actions observed in T2D is triggered mainly by a complex combination of genetic predisposition, body composition, nutritional and environmental factors. Insulin receptor, glucose transporter and post-receptor perturbations are observed in T2D. Eventually, peripheral tissues exposed to chronic compensatory hyperinsulinemia become resistant to insulin [11]. Studies have shown the intestinal microbiota is associated with the development of metabolic diseases, as obese and diabetic subjects present perturbations in the proportions of Firmicutes, Bacteroidetes and Proteobacterias $[4,12]$.

Mammals present sterile gastrointestinal tract at birth, and their microbiota is gradually accumulated after birth through the physical contact with the breast and the environment [13]. Infants' intestinal microbiota is mainly formed by Bifidobacteria and Enterobacteria, and it changes progressively into a more complex pattern, observed in adults [14]. These microorganisms and their metabolites interact with the intestinal epithelial cells differently in the small and large intestines. Such microbiological and biochemical variations are attributed to the distinct anatomical features of these two organs, and also to the mucus produced by goblet cells. Mucus acts as bacterial insulator at intestinal barrier level, but does not fully impede bacterial fragments to diffuse through the intestinal barrier, binding to pattern recognition receptors (PRR). Such phenomenon contributes not only to the maintenance of the intestinal barrier but also to the innate and adaptive immune responses [15].

Diet is pivotal for regulation of the intestinal microbiota, excess of nutrients like saturated [16] and polyunsaturated fatty acids [17] or shortage of oligosaccharides $[18,19]$ and phytochemicals [20] can modify the bacterial metabolic activity [21]. High fat diets modify the intestinal microbiota, leading to increased intestinal permeability and susceptibility to microbial antigens, which ultimately correlates with the occurrence of metabolic endotoxemia and insulin resistance [22].

The molecular mechanisms involved in high fat diets and modulation of the intestinal microbiota are not fully elucidated, but as this typical diet increases fatty acid oxidation in the liver and adipose tissue, the evidence available suggests the reactive oxygen species (ROS) generated reduce mucus production in the intestinal epithelium. Thus, the weakened intestinal barrier integrity allows the translocation of intestinal bacteria [23]. Furthermore, production of malondialdehyde as result of polyunsaturated fatty acid oxidation induces damage to the epithelial cell membranes, increasing intestinal tight junction permeability $[24,25]$.

Diabetic individuals have lower counts of Bifidobacterium and Faecalibacterium prausnitzii, both of them Gram + [26] with anti-inflammatory properties [26,27]. Despite the perturbations already observed in the intestinal microbiota of type 2 diabetic subjects, it is still necessary to elucidate whether the variations in the microbiota, intestinal barrier and metabolic endotoxemia are causes or consequences of diabetes. Interestingly, Mehta et al. [28] showed that acute inflammation induced by intravenous administration of LPS promotes metabolic endotoxemia and systemic insulin resistance, following modulation of specific adipose inflammatory and insulin signaling pathways.

The relationship between LPS and the development of T2D has been observed in some clinical trials [29-33]. Concurrent with metabolic endotoxemia, translocation of live bacteria from the intestinal barrier into the blood appears to be related to the development of T2D [34,35].

One of the features common to metabolic diseases such as obesity and T2D is a mild chronic inflammatory state, which could possibly be - among other factors - the result of TLR activation by LPS, present in the cell wall of Gram- bacteria. The TLRs comprise a large family of cell membrane proteins present in different types of cells, recognizing microbe-associated molecular patterns (MAMPs) during the inflammatory response. TLRs play an important role in the innate immune system due to their ability to detect the presence and nature of pathogens, providing the first line of host defence. However, TLRs also stimulate adaptive immunity, once they induce the secretion of inflammatory cytokines [36]. These receptors feature leucine-rich repeat (LRR) extracellular domains, and Toll/interleukin-1 receptor (TIR) intracellular domains [37].

Toll-like receptors 4 (TLR4) are present in tissues targeted for insulin actions. Such actions may become compromised upon TLR4 stimulation, through activation 
of cytokine signalling cascades alongside increased concentration of reactive oxygen species (ROS) [38,39]. Reduced Bifidobacterium due to a high-fat diet intake has been associated with higher concentrations of LPS, one of the features of metabolic endotoxemia [40]. A high-fat diet intake promotes the death of Gram- bacteria, contributing to LPS production in the gut and its translocation into intestinal capillaries and the general circulation [41]. Such effect leads to higher concentrations of pro-inflammatory cytokines in various tissues via TLR4 activation $[42,5,43]$.

Inflammation levels are pivotal for intestinal microbiota regulation and for the development of insulin resistance. The inflammatory response is activated by MAMPs such as LPS, flagellin, peptidoglycans, damage-associated molecular pattern molecules (DAMPS), high-mobility group protein (HMGB), DNA and nucleotides [36]. The recognition of DAMPS and MAMPs is mediated by specific receptors, including toll-like receptors (TLRs), C-type lectin receptors (CLRs), receptors for advanced glycation end products (RAGE), nucleotide binding oligomerization domain-like receptor (NLR) intracellular domains, and retinoic acid inducible gene type 1 (RIG-1). Activation of such receptors results in phosphorylation of c-Jun N-terminal kinases (JNKs) and IkappaB kinase complexes $(\mathrm{IKK} \beta)$, consequently amplifying the inflammatory response [37].

As TLR4 forms a molecular complex with its soluble myeloid differentiation factor-2 (MD2) co-receptor at cell surface level, it becomes a binding site for LPS. The now formed complex TLR4-MD2-LPS triggers a cascade of inflammatory events, leading to the activation of nuclear factor kappa B (NFkB) via activation of the intracellular Toll-interleukin 1 receptor domain-containing adapter protein (TIRAP), and of the TIR domain-containing adaptor-inducing interferon- $\beta$ [TRIF]-related adaptor molecule (TRAM). TIRAP and TRAM activation triggers the myeloid differentiation factor 88 (MyD88) and the TRIF pathways, respectively. The MyD88 recruits proteins of the families Interleukin-1 receptor-associated kinase (IRAK) and TNF- $\alpha$ receptor-associated factor 6 (TRAF6). TRAF6 is responsible for activation of the transforming growth factor $\beta$-activated kinase 1 (TAK1); activated TAK1 promotes phosphorylation of the kappa beta kinase (IKK) inhibitors $\alpha, \beta$ and $\gamma$ [44].

Phosphorylated IKK complexes degrade the inhibitory kappa B (IkB), translocating the NFKB to the nucleus, subsequently inducing the expression of pro-inflammatory cytokines. Activation of inflammatory pathways induced by LPS-TLR4 increases the expression of inducible nitric oxide synthase [45], promoting the S-nitrosation/Snitrosylation phenomenon. The generated nitric oxide reacts with cysteine residues to form adducts of $\mathrm{S}$ nitrosothiols [46], inhibiting the insulin transduction signal via phosphorylation of insulin receptor 1 substrate (IRS-1) in serine, which in turn leads to insulin resistance in hepatic, muscle and adipose tissues [47,48]. Others studies have shown pro-inflammatory cytokines induce phosphorylation of IRS-1 in serine [49,50], whose activation may mediate the inhibition of insulin receptor tyrosine kinase and protein kinase B (AKT) signalling, also increasing the degradation of IRS-1 [51,52].

\section{Intestinal microbiota and type 1 diabetes}

Type 1 diabetes results from autoimmune destruction of pancreatic $\beta$ cells in genetically predisposed individuals [53]. $\beta$ cell destruction involves innate and adaptive immune responses, and when around $80 \%$ of the $\beta$ cells are affected, the first signs of diabetes become manifested [54]. At this point insulin therapy is mandatory.

Some epidemiological evidence - such as declined incidence of T1D in Caucasian Europeans, increased incidence in children under five in some demographic areas such as North America, Australia and North Africa, as well as T1D discordance in monozygotic twins suggests the contribution of environmental factors for the development of this condition $[55,56]$.

The intestinal mucosa is a major site for pathogen invasion: when undamaged, it provides the first line of defence against antigens. The intestinal wall is constituted of a layer of mucus, IgA-secreting cells, antimicrobial peptides, and a complex system of epithelial barrier formed by adhesion and tight junctions [57]. The intestinal microbiota is capable of modulating the immune response and consequently autoimmunity; the influence of intestinal bacteria in the pathogenesis of T1D has been demonstrated [58].

The mechanisms associating gut microbiota and T1D development are yet to be fully understood. Studies in humans tend to suggest this possibility; however, these results have not yet proven a direct relationship between changes in intestinal microbiota and the development of autoimmune diseases.

Increased intestinal permeability may facilitate the absorption of antigens which can injure pancreatic $\beta$ cells [59]. Individuals susceptible to T1D and other autoimmune diseases present inadequately functioning intestinal barrier [60], allowing greater exposure of antigens to the immune system. However, the mechanisms resulting in this condition - leaky gut - before T1D has developed itself have not yet been fully understood. T1D patients show perturbations in the structure of tight junctions as result of decreased zonulin expression, a protein related to the regulation of intestinal permeability [61], as well as increased paracellular space between intestinal epithelial cells [6].

Antigens of dietary or pathogenic origins, facilitated by increased intestinal permeability, trigger inflammation 
and immune responses, which may lead to destruction of pancreatic $\beta$ cells [62-64]. Bovine insulin for example, which can be found in cow's milk, appears to sensitize intestinal $\mathrm{T}$ lymphocytes in susceptible children, which in turn could participate in the autoimmune destruction of pancreatic $\beta$ cells [65]. Furthermore, changes in intestinal microbiota may result in altered inflammatory responses, an important event in the pathogenesis of autoimmune diseases such as T1D [66]. Children with T1D showed higher counts of Clostridium, Bacteroides and Veillonella, followed by lower counts of Bifidobacterium and Lactobacillus, than healthy children [67]. Another study reported in T1D increased counts of Bacteroides ovatus and decreased Bacteroides fragilis [68].

Intestinal pathophysiology is related to the development of T1D, once increased intestinal permeability is detectable even before the clinical onset of the disease [69]. A pioneering study by Brugman and colleagues [70] found in BioBreeding diabetes-prone (BB) rats that progressed into T1D presented reduced variety of bacteria of the phylum Bacteroidetes, as compared to control rats. Ribosomal RNA analyses of stool samples of BB and BioBreeding diabetes-resistant (BBR) rats showed increased presence of bacteroidetes and clostridium in $\mathrm{BB}$ rats, and increased presence of lactobacilli and bifidobacterium in $\mathrm{BBR}$ rats [71]. The alterations observed in $\mathrm{BB}$ rats may be due to limited functioning of their immune system [72]; however, this causal relationship remains under investigation.

In agreement with these results, a study [73] found that healthy children have more diverse and stable intestinal microbiota as compared to children who developed T1D. In another study, the gut microbiota composition of T1D children showed increased virulence factors, phage, prophage, motility genes and higher response to stress [74]. Corroborating these findings, it has also been found in T1D children lower counts of bacteria producing butyrate, a short chain fatty acid with anti-inflammatory actions [75]. Butyrate reduces bacterial translocation, improves the organization of tight junctions [76] and stimulates the synthesis of mucin, a glycoprotein maintaining the integrity of the intestinal epithelium [77].

MyD88 knockout mice were protected from developing T1D, and showed lower expression of TNF- $\alpha$ in the pancreatic lymph nodes as compared to wild-type mice [78]. The same study found that MyD88 deletion was associated with lower ratios of Firmicutes over Bacteroidetes, and increased counts of Lactobacilli, Rikenellaceae and Porphyromonadaceae. Another experimental study showed that antibiotic administration prevented insulitis and pancreatic $\beta$ cell destruction in mice with virusinduced T1D through mechanisms involving reduction of the innate immune response in pancreatic lymph nodes and Peyer's patches [79]. These results support the hypothesis that the innate immune system is related to the development of T1D.

In contrast, intestinal microbiota destruction of MyD88 knockout rats by broad-spectrum antibiotics was associated with increased incidence of T1D, as compared to germ-free mice [78]. This result suggests that specific components of the intestinal microbiota may prevent the activation of autoimmune $\mathrm{T}$ cells independently of the presence of MyD88 in ways not yet fully understood.

Studies in T1D animal models have elucidated several pathogenic pathways that may lead to immune-mediated destruction of $\beta$ cells. CD8+ cells, for example, can destroy $\beta$ cells via perforin expression. The presence of proinfammatory cytokines induces damage to $\beta$ cells, and molecules of the TNF family induce apoptosis [80].

Studies in humans have also shown involvement of the immune system in the destruction of pancreatic $\beta$ cells. Interferons produced in inflammatory and infectious responses accelerate the destruction of pancreatic $\beta$ cells by inducing the expression of MHC class I [81]. Higher expression of MHC class I epitopes [82] and CD8+ T cells [83] have been observed in the pancreas of T1D individuals. $\mathrm{CD} 4+$ and $\mathrm{CD} 8+\mathrm{T}$ cells are related to the pathogenesis of T1D, once $\mathrm{CD} 4+$ may invade pancreatic islets, and CD8+ may initiate $\beta$ cell destruction [84].

Studies focusing on specific bacterial lineages have revealed that Bacteroides fragilis, a member of the Bacteroidetes phyla [85], present the ability to reduce intestinal inflammation, whilst segmented filamentous bacteria are able to activate IL-17-producing CD4+ $\mathrm{T}$ helper cells (TH17), which stimulate autoimmune responses and the production of inflammatory cytokines [86-88]. Interestingly, TH17 induction is dependent upon the individual's genetic background [86].

It has been proposed the maintenance of normal microbiota - the 'old friends hypothesis' - is promoted by lower modulatory levels of regulatory $\mathrm{T}$ cells secreting IL-10 and transforming growth factor beta (TGF $\beta$ ), which decrease inflammation [89]. Geuking et al. [86] proposes this mutualistic response to be related to a variety of regulatory $\mathrm{T}$ cell subsets in a complex real-life gut flora, inclusive of symbiotic, commensal with the potential to become pathogenic, and pathogenic microorganisms. In that complex scenario, further research is needed to specify which Bacteroidetes species reduce intestinal inflammation and promote regulatory $\mathrm{T}$ cells induction. Taken together however, these responses support the maintenance of self-tolerance, and suggest an important role of probiotics in maintaining a healthier intestinal microbiota [64].

\section{Evidences from experimental and clinical studies}

Probiotics are a class of live microorganisms which, when ingested in appropriate amounts, may confer health 
benefits to their host [90]. Consumption of probiotics may be associated with immune system stimulation, decreased cholesterol blood levels, protection against respiratory and intestinal diseases, reduction of inflammatory responses and antitumorigenic effects. These alleged health claims apparently stem from the ability of probiotics to secrete antimicrobial substances, competing with other pathogens, strengthening the intestinal barrier and modulating the immune system [91]. Bifidobacteria and lactobacilli are the most commonly used strains in functional foods and dietary supplements [92]. A summarized list of studies evaluating the effects of probiotic administration in experimental models and clinical investigations in diabetes mellitus is presented in Tables 1 and 2 .

It has been shown that Lactobacillus acidophilus, $L$ fermentum, L gasseri and L rhamnosus modulate the expression of genes encoding junction and adhesion proteins E-cadherin and $\beta$-catenin, and reduce the expression of protein kinase $C-\delta(\mathrm{PKC}-\delta)$ [93]. PKC- $\delta$ activation results in dispersion of adherence junctions, increasing intestinal permeability [94]. On the other hand, $\beta$-catenin phosphorylation induced by probiotics may strengthen the complex E-cadherin $/ \beta$-catenin, supporting the maintenance of adhesion junction from the binding site of E-cadherin to the cytoskeleton [95].

The administration of $10^{8}$ colony-forming units (CFU) of Lactobacillus johnsonii N6.2 per day to rats increased the number of Paneth cells [96]. Paneth cells are constituents of the intestinal barrier which produce antimicrobial proteins, contributing to reduce intestinal permeability [97]. Experimental studies have shown the administration of Lactobacillus johnsonii to diabetes-prone rats may reduce the incidence of diabetes by increasing the gene expression of claudin- 1 and decreasing oxidative stress [98], and it may also modulate the $\mathrm{TH} 17$ response, impairing the development of T1D in diabetes-prone mice [99]. Several microbial species possess the ability to modulate the TH17 phenotype, particularly Gram + bacteria [100]. Even though TH17 induces pancreatic inflammation, progression to T1D will occur only after this cell differentiates into $\mathrm{TH} 1$; so apparently the formation of differentiated TH17 phenotypes appears to inhibit the manifestation of the diabetogenic phenotype [101].

The consumption of dahi, a traditional Indian fermented milk, containing $L$. acidophilus, $L$. casei and L. lactis has been shown to reduce the glycemic curve and HbA1c [102]. L. plantarum DSM15313 is also suggested to reduce glycaemia, improve glucose tolerance and reduce insulin resistance [103]. VSL\#3, a commercially available mixture of probiotics containing $3 \times 10^{11} \mathrm{CFU} / \mathrm{g}$ of Bifidobacterium longum, B. infantis and B. breve, has been shown to improve insulin signalling and reduce inflammation in the adipose tissue of ApoE-/- rats [104]. VSL\#3 has been also shown to reduce the depletion of hepatic natural killer cells and minimize the activation of NFkB in wild-type male C57BL6 mice fed a high fat diet [105]. A study investigating the effects of VSL\#3 on the occurrence of diabetes in non-obese diabetic mice showed this probiotic mixture has impaired the development of T1D via three major pathways: 1) supressing both inflammation and pancreatic $\beta$ cell death, 2) increasing the production of IL-10 from Peyer's patches, a component of the gutassociated lymphoid tissue, and 3) increasing the IL-10 expression in the pancreas [106]. IL-10 is an anti-inflammatory cytokine which inhibits antigen presentation and proinflammatory cytokine production [107], whereas depletion of hepatic natural killer cells is linked to the development of hepatic insulin resistance [108].

Consumption of dahi enriched with Lactobacillus acidophilus NCDC14 and Lactobacillus casei NCDC19 has apparently reduced lipid peroxidation, $\mathrm{HbA} 1 \mathrm{c}$ and ameliorated intestinal transit in diabetic rats; however, without concomitant blood glucose reduction [109]. Similar study has shown preserved enzymatic activity of the antioxidant enzymes glutathione peroxidase, superoxide dismutase and catalase [110]. The administration of Lactobacillus reuteri GMNL-263 has been shown to reduce glycaemia and HbA1c levels, and to prevent renal fibrosis [111]. It has also been suggested that Bifidobacterium adolescentis improves insulin sensitivity [112] via increased production of glucagon-like peptide 1 (GLP-1) [2]. GLP-1 enhances glucose tolerance via complex mechanisms involving modulation of insulin secretion, pancreatic cell mass and food intake [113].

Administration of $10^{9} \mathrm{CFU}$ of Bifidobacterium animalis ssp. lactis 420 to high fat diet-fed diabetic rats appears to reduce the inflammatory cytokines TNF- $\alpha$, IL- $1 \beta$, plasminogen activator inhibitor-1 (PAI-1) and IL-6 in mesenteric adipose tissue, as well as to improved insulin sensitivity [34]. In the same way, Lactobacillus rhamnosus GG appears to reduce translocation of NFkB to the nucleus, degradation of $\operatorname{Ik} \beta$, and activation of the TLR4 by LPS [114].

Intestinal microbiota modulation by probiotics appears to offer beneficial outcomes to insulin-resistant individuals via mechanisms both related and unrelated to inflammation [115]. However, the effectiveness of clinical trials employing probiotics may be specific to the strain used and cannot be extrapolated to other strains or species [116].

A study has shown daily consumption of $200 \mathrm{ml}$ of a shake containing $4 \times 10^{8} \mathrm{CFU} / 100 \mathrm{ml}$ of Lactobacillus acidophilus, $4 \times 10^{8} \mathrm{CFU} / 100 \mathrm{ml}$ of Bifidobacterium bifidum and $1 \mathrm{~g} / 100 \mathrm{ml}$ of fructooligosaccharides, resulted in blood glucose reduction in T2D individuals [8]. It has also been shown that T2D individuals, after consuming a yogurt containing $7,23 \times 10^{6} \mathrm{CFU}$ of L. acidophilus La5 and $6,04 \times 10^{6} \mathrm{CFU}$ of $\mathrm{B}$. lactis Bb12 for 6 weeks, presented reduced fasting glucose and reduced HbA1c levels, followed 
Table 1 Effects of probiotic administration on diabetes mellitus - Experimental studies

\begin{tabular}{|c|c|c|c|c|c|}
\hline References & Probiotics & Type of cell/animal model & Quantity & Study period & Results \\
\hline \multirow[t]{2}{*}{ [34] } & \multirow[t]{2}{*}{ Bifidobacterium animalis subsp. lactis 420} & \multirow{2}{*}{$\begin{array}{l}\text { C57BL/6, ob/ob, CD14-/-, } \\
\text { ob/obxCD14-/-, Myd88-/-, } \\
\text { Nod1-/-or Nod2-/-mice } \\
\text { fed a high fat diet }\end{array}$} & \multirow[t]{2}{*}{$10^{9} \mathrm{CFU} /$ day } & \multirow[t]{2}{*}{6 weeks } & $\downarrow$ TNF- $a, I L-1 \beta$, PAI-1 and IL-6 \\
\hline & & & & & $\uparrow$ Insulin sensitivity \\
\hline \multirow[t]{3}{*}{ [94] } & \multirow[t]{3}{*}{$\begin{array}{l}\text { L. acidophilus (PZ 1041), L. gasseri } \\
\text { (PZ 1160), L. fermentum (PZ 1162), } \\
\text { and L. rhamnosus (PZ 1121) }\end{array}$} & \multirow[t]{3}{*}{ T84 cell } & \multirow[t]{3}{*}{-} & \multirow[t]{3}{*}{-} & $\begin{array}{l}\text { L. acidophilus, L. fermentum, and L. gasseri: } \\
\uparrow \text { two genes encoding adherence junction } \\
\text { proteins } \beta \text {-catenin and E-cadherin }\end{array}$ \\
\hline & & & & & $\uparrow$ Transepithelial electrical resistance \\
\hline & & & & & $\downarrow P K C \delta$ \\
\hline [96] & $\begin{array}{l}\text { Lactobacillus johnsonii N6.2 subsp. } \\
\text { infantis ATCC }\end{array}$ & Caco-2 cell/BB rats & $\begin{array}{l}10^{10} \text { to } 10^{11} \mathrm{CFU} / \mathrm{L} \text { in cell culture } \\
\text { and } 10^{8} \mathrm{CFU} / \text { day in rats }\end{array}$ & - & $\uparrow$ Paneth cell \\
\hline [99] & $\begin{array}{l}\text { Lactobacillus johnsonii N6.2 and } \\
\text { Lactobacillus reuteri TD1 }\end{array}$ & BB rats & $10^{8} \mathrm{CFU} /$ day & 141 days & $\begin{array}{l}\text { Lactobacillus johnsonii N6.2: } \downarrow \text { incidence of T1D; } \\
\uparrow \text { goblet cells and claudin- } 1 ; \downarrow \text { hexanoyl-lysine } \\
\text { (oxidative stress biomarker) }\end{array}$ \\
\hline [100] & $\begin{array}{l}\text { Lactobacillus johnsonii N6.2 and } \\
\text { Lactobacillus reuteri TD1 }\end{array}$ & $\begin{array}{l}\text { BB rats, NOD mice, and } \\
\text { C57BL/6 mice }\end{array}$ & $1 \times 10^{8}$ CFU/day & 140 days & Positive TH17 phenotype modulation \\
\hline [102] & L. acidophilus, L. casei, and L. lactis & $\begin{array}{l}\text { Male Wistar rats fed a } \\
\text { high fructose diet }\end{array}$ & $\begin{array}{l}\text { diet supplemented with } \\
15 \% \text { of dahi ad libitum }\end{array}$ & 8 weeks & $\begin{array}{l}\downarrow \text { Blood glucose, HbA1c, glucose intolerance, } \\
\text { plasma insulin, liver glycogen, plasma total } \\
\text { cholesterol, triacylglycerol, low-density lipoprotein } \\
\text { cholesterol, very low-density lipoprotein cholesterol, } \\
\text { and blood free fatty acids }\end{array}$ \\
\hline [103] & L. plantarum DSM 15313 & $\begin{array}{l}\text { Female C57BL/6 J mice } \\
\text { fed a high fat diet }\end{array}$ & $25 \times 10^{8}$ CFU/day & 20 weeks & $\downarrow$ Blood glucose \\
\hline \multirow[t]{5}{*}{ [104] } & \multirow{5}{*}{$\begin{array}{l}\text { VSL\#3 (L. acidophilus MB 443, L. delbrueckii } \\
\text { subsp. bulgaricus MB 453, L. casei MB 451, } \\
\text { L. plantarum MB 452, B. longum Y10, } \\
\text { B. infantis Y1, B. breve Y8, and S. salivarius } \\
\text { subsp. thermophilus MB 455) }\end{array}$} & \multirow[t]{5}{*}{ ApoE-/-C57BL6 male mice } & \multirow[t]{5}{*}{$25 \times 10^{8}$ CFU/day } & \multirow[t]{5}{*}{12 weeks } & $\downarrow$ Insulin \\
\hline & & & & & $\uparrow$ Glucose tolerance \\
\hline & & & & & $\uparrow$ Insulin signaling \\
\hline & & & & & $\downarrow T N F-a$ and RANTES \\
\hline & & & & & $\uparrow \mathrm{IL}-10$ \\
\hline \multirow[t]{4}{*}{ [105] } & \multirow{4}{*}{$\begin{array}{l}\text { VSL\#3 (L. acidophilus MB 443, L. delbrueckii } \\
\text { subsp. bulgaricus MB 453, L. casei MB 451, } \\
\text { L. plantarum MB } 452, \text { B. longum Y10, B. } \\
\text { infantis Y1, B. breve Y8, and S. salivarius } \\
\text { subsp. thermophilus MB 455) }\end{array}$} & \multirow[t]{4}{*}{ NOD mice } & \multirow[t]{4}{*}{$1.5 \times 10^{9} \mathrm{CFU} /$ day } & \multirow[t]{4}{*}{12 weeks } & $\downarrow$ Hepatic NKT cell depletion \\
\hline & & & & & $\downarrow$ IKK $\beta$ activity \\
\hline & & & & & $\downarrow N F-K B$ binding activity \\
\hline & & & & & 个Insulin signaling \\
\hline \multirow[t]{3}{*}{ [106] } & \multirow{3}{*}{$\begin{array}{l}\text { VSL\#3 (L. acidophilus MB 443, L. delbrueckii } \\
\text { subsp. bulgaricus MB 453, L. casei MB 451, } \\
\text { L. plantarum MB } 452, \text { B. longum Y10, B. } \\
\text { infantis Y1, B. breve Y8, and S. salivarius } \\
\text { subsp. thermophilus MB 455) }\end{array}$} & \multirow[t]{3}{*}{ Female NOD mice } & \multirow[t]{3}{*}{$9 \mathrm{mg} /$ week } & \multirow[t]{3}{*}{70 weeks } & $\downarrow$ Incidence of auto-immune diabetes \\
\hline & & & & & $\downarrow$ Insulitis and decreased rate of $\beta$-cell destruction \\
\hline & & & & & $\uparrow I L-10$ \\
\hline
\end{tabular}


Table 1 Effects of probiotic administration on diabetes mellitus - Experimental studies (Continued)

[109]

Lactococcus lactis ssp. diacetylactis NCDC 60, Male Wistar diabetic rats

$15 \mathrm{~g} /$ day $(8,83 \mathrm{CFU} / \mathrm{g}$ lactobacili and 7,89 log CFU/g lactococci)

15 weeks

$\uparrow$ Gastric emptying

L. acidophilus NCDC 14 , and L. casei NCDC 19

(1)

Dahi probiotic feeding did not change blood glucose levels

$\downarrow$ Thiobarbituric acid-reactive species in

intestinal tissues

$[111]$

L. reuteri GMNL-263

Male Sprague-Dawley

$1 \times 10^{9}$ CFU/day

$\downarrow \mathrm{HbA} 1 \mathrm{c}$

diabetic rats

4 weeks

$\downarrow$ HbA1c and blood glucose

Male Wistar rats fed a

high fat diet

$\downarrow$ JAK2 and STAT1 phosphorylation

$\downarrow$ PAI-1

[112] Bifidobacterium adolescentis

HT-29 cells

12 weeks

$\downarrow$ Body weight

$\uparrow$ Insulin sensitivity

[114] Lactobacillus rhamnosus GG

$10^{7}-10^{9} \mathrm{CFU} / \mathrm{mL}$

$\downarrow N F-k B$ nuclear translocation

$\downarrow$ LPS-induced IKBa degradation

HbA1c: Glycated hemoglobin; NF-kB: nuclear factor kappa B; LPS: Lipopolysaccharides; IKBa: inhibitory kappa B alpha; TNF-a: tumor necrosis factor alpha; IL-1 B: interleukin-1 beta; PAl-1: plasminogen activator inhibitor-1; IL-6; HbA1c: Glycated hemoglobin; NF-kB: nuclear factor kappa B; LPS: Lipopolysaccharides; IKBa: inhibitory kappa B alpha; TNF-a: tumor necrosis factor alpha; IL-1 : interleukin-1 beta; PAl-1: plasminogen activator inhibitor-1; IL-6:
interleukin-6; JAK2: Janus kinase 2; STAT1: signal transducer and activator of transcription 1; IL-10: interleukin-10; IKKß: inhibitors of kappa beta kinase beta; NKT: natural killer T cells; RANTES: regulated upon activation, normal interleukin-6; JAK2: Janus kinase 2; STATI: signal transducer and activst 
Table 2 Effects of probiotic administration on diabetes mellitus - clinical studies

\begin{tabular}{|c|c|c|c|c|c|c|}
\hline References & Probiotic & Study design/subjects & Sample Size & Quantity & Study period & Results \\
\hline [8] & $\begin{array}{l}\text { Lactobacillus acidophilus } \\
\text { and Bifidobacterium bifidum }\end{array}$ & $\begin{array}{l}\text { Double-blinded, placebo-controlled, } \\
\text { randomized study, T2D females } \\
\text { aged } 50-65 \text { years }\end{array}$ & $\begin{array}{l}\text { Placebo group: } n=10 ; \\
\text { Probiotic group: } n=10\end{array}$ & $\begin{array}{l}2 \text { daily doses of } 100 \mathrm{~mL} \text { symbiotic } \\
\text { shake containing } 4 \times 10^{8} \mathrm{CFU} / 100 \mathrm{~mL} \\
\text { Lactobacillus acidophillus, } 4 \times 10^{8} \\
\text { CFU/100 } \mathrm{mL} \text { Bifidobacterium bifidum }\end{array}$ & 45 days & $\downarrow$ Glycemia \\
\hline \multirow[t]{3}{*}{ [9] } & \multirow{3}{*}{$\begin{array}{l}\text { Lactobacillus acidophilus } \\
\text { La5 and Bifidobacterium } \\
\text { lactis Bb12 }\end{array}$} & \multirow{3}{*}{$\begin{array}{l}\text { Double-blinded, randomized } \\
\text { controlled clinical trial, T2D } \\
\text { patients aged } 30-60 \text { years }\end{array}$} & \multirow[t]{3}{*}{$\begin{array}{l}\text { Placebo group: } \mathrm{n}=32 \\
\text { Probiotic group: } \mathrm{n}=32\end{array}$} & \multirow{3}{*}{$\begin{array}{l}300 \mathrm{~g} / \text { day of probiotic and conventional } \\
\text { yogurt day } 1: 7,23 \times 10^{6} \text { of } L \text {. acidophilus } \\
\text { La5 and } 6.04 \times 10^{6} \text { cfu/g of B. lactis Bb12 }\end{array}$} & \multirow[t]{3}{*}{6 weeks } & $\begin{array}{l}\downarrow \text { Fasting blood } \\
\text { glucose and } \mathrm{HbA} 1 \mathrm{c}\end{array}$ \\
\hline & & & & & & $\begin{array}{l}\uparrow \text { Erythrocyte SOD } \\
\text { and GPx }\end{array}$ \\
\hline & & & & & & $\begin{array}{l}\uparrow \text { Total antioxidant } \\
\text { capacity }\end{array}$ \\
\hline \multirow[t]{2}{*}{ [10] } & \multirow[t]{2}{*}{ L. acidophilus NCFM } & \multirow[t]{2}{*}{$\begin{array}{l}\text { Double-blinded, placebo-controlled, } \\
\text { randomized study, T2D males }\end{array}$} & \multirow[t]{2}{*}{$\begin{array}{l}\text { Placebo group: } n=24 ; \\
\text { Probiotic group: } n=24\end{array}$} & \multirow[t]{2}{*}{-} & \multirow[t]{2}{*}{4 weeks } & $\begin{array}{l}\text { Preserved insulin } \\
\text { sensitivity }\end{array}$ \\
\hline & & & & & & $\begin{array}{l}\text { No effect on systemic } \\
\text { inflammatory response }\end{array}$ \\
\hline [117] & $\begin{array}{l}\text { Lactobacillus rhamnosus } \\
\text { GG (ATCC } 53 \text { 103) and } \\
\text { Bifidobacterium lactis Bb12 }\end{array}$ & $\begin{array}{l}\text { Prospective, randomized study, } \\
\text { mother-baby pairs }\end{array}$ & $\begin{array}{l}\text { Dietetic Intervention + probiotics: } \\
n=85 ; \text { Dietetic Intervention + placebo: } \\
n=86 ; \text { Control + placebo: } n=85\end{array}$ & $\begin{array}{l}\text { Lactobacillus rhamnosus GG: } 10^{10} \\
\text { CFU/day; Bifidobacterium lactis } \\
\text { Bb12: } 10^{10} \text { CFU/day }\end{array}$ & 33 months & $\downarrow$ Risk of GDM \\
\hline \multirow[t]{3}{*}{ [118] } & \multirow{3}{*}{$\begin{array}{l}\text { Lactobacillus rhamnosus } \\
\text { GG, ATCC } 53103 \text { and } \\
\text { Bifidobacterium lactis Bb12 }\end{array}$} & \multirow{3}{*}{$\begin{array}{l}\text { Randomized, prospective, parallel- } \\
\text { group, combined dietary counselling, } \\
\text { pregnant women }\end{array}$} & \multirow{3}{*}{$\begin{array}{l}\text { Diet + probiotics: } n=85 ; \text { Diet + placebo: } \\
n=86 ; \text { Control + placebo: } n=85\end{array}$} & \multirow{3}{*}{$\begin{array}{l}\text { Lactobacillus rhamnosus: } 10^{10} \\
\text { CFU/day; Bifidobacterium lactis } \\
\text { Bb12: } 10^{10} \text { CFU/day }\end{array}$} & \multirow[t]{3}{*}{18 months } & $\downarrow$ Blood glucose \\
\hline & & & & & & $\downarrow$ Insulin \\
\hline & & & & & & $\downarrow$ Insulin sensitivity \\
\hline \multirow[t]{2}{*}{ [119] } & \multirow[t]{2}{*}{ L. plantarum WCFS1 } & \multirow[t]{2}{*}{$\begin{array}{l}\text { Double-blinded, randomized } \\
\text { crossover study, healthy subjects }\end{array}$} & \multirow[t]{2}{*}{$n=14$} & \multirow[t]{2}{*}{$10^{12} \mathrm{CFU}$} & 6 hours & $\begin{array}{l}\downarrow \text { Degradation of } \\
\text { transepithelial electrical } \\
\text { resistance }\end{array}$ \\
\hline & & & & & & $\uparrow$ ZO-1 in tight junction \\
\hline
\end{tabular}

GDM: gestational diabetes mellitus; GPx: Glutathione peroxidase; HbA1c: Glycated hemoglobin; SOD: Superoxide dismutase; T2D: type II diabetes mellitus; ZO-1: zonula occludens-1. 


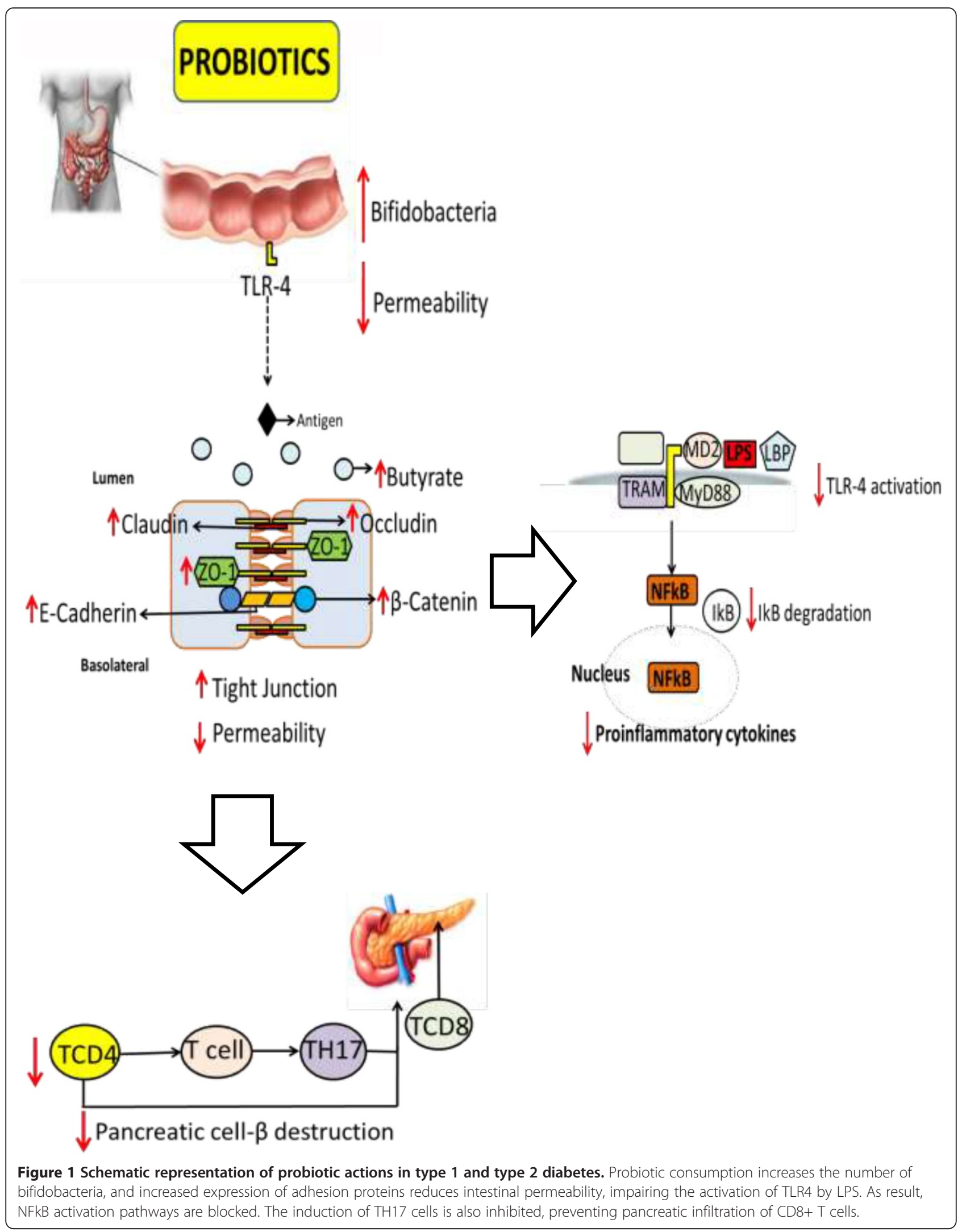


by higher activity of superoxide dismutase and glutathione peroxidase, as compared to a control group [9].

The administration of capsules containing $10^{10} \mathrm{CFU}$ of L. acidophilus NCFM for 4 weeks has preserved insulin sensitivity in a sample population of non-diabetic and diabetic individuals [10]. Pregnant women receiving intensive nutritional counselling and a food supplement containing $10^{10} \mathrm{CFU}$ of L. rhamnosus GG and $10^{10} \mathrm{CFU}$ of B. lactis $\mathrm{Bb} 12$ presented improved glucose tolerance and reduced HbA1c levels in relation to a control group receiving only a control, healthy diet [117]. A similar study from the same research group observed that nutritional counselling combined with probiotic supplementation reduced blood glucose during pregnancy and up to 12 months after delivery, reduced insulin concentrations and improved insulin sensitivity more effectively than nutritional counselling alone [118].

A study has shown the consumption of $10^{12} \mathrm{CFU}$ of Lactobacillus plantarum WCFS1 improved the localization of the scaffolding protein zonula occludens (ZO)- 1 in areas surrounding the tight junctions [119]. Accumulation of these proteins is associated with increased protection at intestinal barrier level [120], and the organization of these occlusion proteins may occur via activation of TLR2 receptors on the apical surface of the intestinal epithelium [119].

Molecular mechanisms involving the anti-diabetic effects of probiotics are not fully elucidated, but may be related to reduction of oxidative stress, immunomodulation, attenuation of inflammation and modification of the intestinal microbiota (Figure 1) [9]. Furthermore, probiotics have been shown to improve the absorption of antioxidants and reduce post-prandial lipid concentrations, actions directly related to oxidative stress [121].

\section{Conclusions}

The intestinal microbiota presents a vast set of antigens which may participate in the modulation of immunological diseases. An intestinal barrier presenting full integrity ensures specific interactions between the luminal antigens and the host. Functional disarrangements may contribute to the autoimmune destruction of pancreatic $\beta$ cells, which leads to T1D, and increased expression of inflammatory cytokines may lead to insulin resistance and T2D.

The evidence available from experimental studies and clinical trials supports our suggestion that the modulation of the intestinal microbiota by probiotics may be effective towards prevention and management of T1D and T2D. The findings discussed here provide an insight into the investigation of further hypotheses aiming to elucidate molecular mechanisms involved in the modulation of intestinal microbiota by probiotic administration, their roles on the development of T1D and T2D and potential effectiveness for clinical practice.

\section{Abbreviations}

AGE: Advanced glycation end products; AKT: Protein kinase B; AP-1: Activating protein 1; BB: BioBreeding diabetes-prone; BBR: BioBreeding diabetes-resistant; CFU: Colony-forming units; CLRs: C-type lectin receptors; CREB: CRE binding protein; DAMPS: Damage-associated molecular pattern molecules; FFA: Free fatty acid; GLP-1: Glucagon-like peptide 1; GSK-3: Glycogen synthase kinase 3; HbA1c: Glycosylated haemoglobin; HMGB: High-mobility group protein; IKB: Inhibitory kappa B; IKK: Inhibitors of kappa beta kinase; IKKB: Inhibitors of kappa beta kinase beta; IRAK: Interleukin-1 receptor-associated kinase; IRF3: Interferon-regulatory factor 3; IRS-1: Insulin receptor 1 substrate; JNKs: c-Jun N-terminal kinases; LPS: Lipopolysacharide; LRR: Leucine-rich repeat; MAPK-p38: Mitogen-activated protein kinase p38; MD2: Myeloid differentiation factor 2; MyD88: Myeloid differentiation factor 88; NFkB: Nuclear factor kappa B; NOD: Nucleotide-binding oligomerization domain receptor; NLR: Nucleotide binding oligomerization domain-like receptor (NLR) PAl-1, plasminogen activator inhibitor-1; PKC: Protein kinase C; PRR: Pattern recognition receptors; RAGE: Receptors for advanced glycation end products; RIG-1: Intracellular domains, and retinoic acid inducible gene type 1; ROS: Reactive oxygen species; SciELO: The Scientific Electronic Library Online SOCS3, suppressor of cytokine signalling 3; T1D: Type 1 diabetes mellitus; T2D: Type 2 diabetes mellitus; TAK1: Transforming growth factor $\beta$-activated kinase 1; TIR: Toll/interleukin-1 receptor; TIRAP: Intracellular Toll-interleukin 1 receptor domain-containing adapter protein; TLRs: Toll-like receptors; TLR4: Toll-like receptor 4; TNF-a: Tumor necrosis factor alpha; TRAF6: TNF-a receptor-associated factor 6; TRAM: TRIF-related adaptor molecule; TRIF: TIR-domain-containing adaptor-inducing interferon- $\beta$; ZO: Zonula occludens.

\section{Competing interests}

The authors declare that they have no competing interests.

\section{Authors' contributions}

ACG drafted the manuscript and performed the design of the study. $A A B$, RGMS and JFM drafted and revised the manuscript. All authors have read and approved the final version of this manuscript.

\section{Authors' information}

ACG: Graduated in Nutrition, Federal University of Goiás (2011), MSc in Nutrition and Health, Federal University of Goiás.

AAB: Graduated in Biological Sciences Medical Modality, Federal University of São Paulo (2000), MPhil in Nutrition Sciences, Federal University of São Paulo (2003), PhD in Nutrition Sciences, Federal University of São Paulo, Post-doctoral researcher in Nutritional Biochemistry, Institute of Brain Chemistry and Human Nutrition, London, currently Senior Lecturer at the Institute of Science and the Environment University of Worcester.

RGMS: Graduated in Nutrition, Federal University of Goiás (2008), MSc in Nutrition and Health, Federal University of Goiás.

JFM: Graduated in Nutrition, Pontifícia Universidade Católica de Campinas (2002), MSc in Pathology, São Paulo State University (2007), PhD in Nutrition, Federal University of São Paulo (2011), member of the Department of Nutrition and Metabolism of the Brazilian Diabetes Society, currently Senior Lecturer at Federal University of Goiás.

\section{Acknowledgements}

This work was supported by Fundação de Amparo à Pesquisa do Estado de Goiás (FAPEG), Brazil.

\section{Author details}

'Laboratório de Investigação em Nutrição Clínica e Esportiva (Labince). Faculdade de Nutrição, Universidade Federal de Goiás, Rua 227 Qd. 68s/nº Setor Leste Universitário, Goiânia, Goiás, Brazil. ${ }^{2}$ Institute of Science and the Environment, University of Worcester, Henwick Grove, Worcester WR2 6AJ, UK.

Received: 11 November 2013 Accepted: 12 June 2014 Published: 17 June 2014

\section{References}

1. WHO - World Health Organization: World Health Statistics WHO/FAO. Geneva: WHO; 2012.

2. Cani PD, Daubioul CA, Reusens B, Remacle C, Catillon G, Delzenne NM: Involvement of endogenous glucagon-like peptide-1 amide on 
glycaemia-lowering effect of oligofructose in streptozotocin-treated rats. J Endocrinol 2005, 185:457-465.

3. Holmes E, Li JV, Athanasiou T, Ashrafian H, Nicholson JK: Understanding the role of gut microbiome-host metabolic signal disruption in health and disease. Trends Microbiol 2011, 19:349-359.

4. Larsen N, Vogensen FK, Berg FW, Nielsen DS, Andreasen AS, Pedersen BK, Al-Soud WA, Sørensen SJ, Hansen LH, Jakobsen M: Gut microbiota in human adults with type 2 diabetes differs from non-diabetic adults. PLoS One 2010, 5:e9085.

5. Cani PD, Bibiloni R, Knauf C, Waget A, Neyrinck AM, Delzenne NM, Burcelin $R$ : Changes in gut microbiota control metabolic endotoxemia-induced inflammation in high-fat diet-induced obesity and diabetes in mice. Diabetes 2008, 57:1470-1481.

6. Secondulfo M, Lafusco D, Carratu R, de Magistris L, Sapone A, Generoso M, Mezzogiomo A, Sasso FC, Cartenì M, De Rosa R, Prisco F, Esposito V: Ultrastructural mucosal alterations and increased intestinal permeability in non-celiac, type I diabetic patients. Dig Liver Dis 2004, 36:35-45.

7. Floch MH, Montrose DC: Use of probiotics in humans: an analysis of the literature. Gastroenterol Clin North Am 2005, 34:547-570.

8. Moroti C, Souza Magri LF, Costa MR, Cavallini DC, Sivieri K: Effect of the consumption of a new symbiotic shake on glycemia and cholesterol levels in elderly people with type 2 diabetes mellitus. Lipids Health Dis 2012, 11:29.

9. Ejtahed HS, Mohtadi-Nia J, Homayouni-Rad A, Niafar M, Asghari-Jafarabadi M, Mofid V: Probiotic yogurt improves antioxidant status in type 2 diabetic patients. Nutrition 2012, 28:539-543.

10. Andreasen AS, Larsen N, Pedersen-Skovsgaard T, Berg RM, Møller K, Svendsen KD, Jakobsen M, Pedersen BK: Effects of Lactobacillus acidophilus NCFM on insulin sensitivity and the systemic inflammatory response in human subjects. Br J Nut 2010, 104:1831-1838.

11. Abdul-Ghani MA, Defronzo RA: Pathogenesis of insulin resistance in skeletal muscle. J Biomed Biotechnol 2010, 2010:476279.

12. Ley RE, Turnbaugh PJ, Klein S, Gordon Jl: Microbial ecology: Human gut microbes associated with obesity. Nature 2006, 444:1022-1023.

13. Mackie Rl, Sghir A, Gaskins HR: Developmental microbial ecology of the neonatal gastrointestinal tract. Am J Clin Nutr 1999, 69:1035S-1045S.

14. Zoetendal EG, Rajilic-Stojanovic M, Vos WM: High-throughput diversity and functionality analysis of the gastrointestinal tract microbiota. Gut 2008, 57:1605-1615.

15. Wells JM, Rossi O, Meijerink M, van Baarlen P: Epithelial crosstalk at the microbiota-mucosal interface. Proc Natl Acad Sci 2011, 108:4607-4614.

16. De La Serre CB, Ellis CL, Lee J, van Baarlen P: Propensity to high-fat diet-induced obesity in rats is associated with changes in the gut microbiota and gut inflammation. Am J Physiol Gastrointest Liver Physiol 2010, 299:G440-G448.

17. Kankaanpää PE, Salminen SJ, Isolauri E, Lee YK: The influence of polyunsaturated fatty acids on probiotic growth and adhesion. FEMS Microbiol Lett 2001, 194:149-153.

18. Roberfroid MB: Prebiotics: the concept revisited. J Nutr 2007, 137:830S-837S

19. Shoaf K, Mulvey GL, Armstrong GD, Hutkins RW: Prebiotic galactooligosaccharides reduce adherence of enteropathogenic Escherichia coli to tissue culture cells. Infect Immun 2006, 74:6920-6928.

20. Gee JM, Johnson IT: Polyphenolic compounds: interactions with the gut and implications for human health. Curr Med Chem 2001, 8:1245-1255.

21. Serino M, Luche E, Chabo C, Amar J, Burcelin R: Intestinal microflora and metabolic diseases. Diabetes Metab 2009, 35:262-272.

22. Cani PD, Amar J, Iglesias MA, Poggi M, Knauf C, Bastelica D, Neyrinck AM, Fava F, Tuohy KM, Chabo C, Waget A, Delmée E, Cousin B, Sulpice T, Chamontin B, Ferrières J, Tanti JF, Gibson GR, Casteilla L, Delzenne NM, Alessi MC, Burcelin R: Metabolic endotoxemia initiates obesity and insulin resistance. Diabetes 2007, 56:1761-1772.

23. Brownleea IA, Knighta J, Dettmarb PW, Pearson JP: Action of reactive oxygen species on colonic mucus secretions. Free Radic Biol Med 2007, 43:800-808.

24. Hall DM, Buettner GR, Oberley LW, Xu L, Matthes RD, Gisolfi CV: Mechanisms of circulatory and intestinal barrier dysfunction during whole body hyperthermia. Am J Physiol Heart Circ Physiol 2001, 280:H509-H521.

25. Muccioli GG, Naslain D, Bäckhed F, Reigstad CS, Lambert DM, Delzenne NM, Cani PD: The endocannabinoid system links gut microbiota to adipogenesis. Mol Syst Biol 2010, 6:392-405.

26. Furet JP, Kong LC, Tap J, Poitou C, Basdevant A, Bouillot JL, Mariat D, Corthier G, Doré J, Henegar C, Rizkalla S, Clément K: Differential adaptation of human gut microbiota to bariatric surgery-induced weight loss: links with metabolic and low-grade inflammation markers. Diabetes 2010, 59:3049-3057

27. O'Mahony D, Murphy S, Boileau T, Park J, O'Brien F, Groeger D, Konieczna P, Ziegler M, Scully P, Shanahan F, Kiely B, O'Mahony L: Bifidobacterium animalis AHC7 protects against pathogen-induced NF-kappaB activation in vivo. BMC Immunol 2010, 11:63.

28. Mehta NN, McGillicuddy FC, Anderson PD, Hinkle CC, Shah R, Pruscino L, Tabita-Martinez J, Sellers KF, Rickels MR, Reilly MP: Experimental endotoxemia induces adipose inflammation and insulin resistance in humans. Diabetes 2010, 59:172-181.

29. Creely SJ, MCTernan PG, Kusminski CM, Fisher FM, Da Silva NF, Khanolkar M, Evans M, Harte AL, Kumar S: Lipopolysaccharide activates an innate immune system response in human adipose tissue in obesity and type 2 diabetes. Am J Physiol Endocrinol Metab 2007, 292:E740-E747.

30. Dixon AN, Valsamakis G, Hanif MW, Field A, Boutsiadis A, Harte A, McTernan $P G$, Barnett $A H$, Kumar S: Effect of the orlistat on serum endotoxin lipopolysaccharide and adipocytokines in South Asian individuals with impaired glucose tolerance. Int J Clin Pract 2008, 62:1124-1129.

31. Al-Attas OS, Al-Daghri NM, Al-Rubeaan K, da Silva NF, Sabico SL, Kumar S, McTernan PG, Harte AL: Changes in endotoxin levels in T2DM subjects on anti-diabetic therapies. Cardiovasc Diabetol 2009, 8:20.

32. Ghanim H, Abuaysheh S, Sia CL, Korzeniewski K, Chaudhuri A, Fernandez-Real $J M$, Dandona P: Increase in plasma endotoxin concentrations and the expression of Toll-like receptors and suppressor of cytokine signaling-3 in mononuclear cells after a high-fat, high-carbohydrate meal: implications for insulin resistance. Diabetes Care 2009, 32:2281-2287.

33. Pussinen PJ, Havulinna AS, Lehto M, Sundvall J, Salomaa V: Endotoxemia is associated with an increased risk of incident diabetes. Diabetes Care 2011, 34:392-397.

34. Amar J, Chabo C, Waget A, Klopp P, Vachoux C, Bermúdez-Humarán LG, Smirnova N, Bergé M, Sulpice T, Lahtinen S, Ouwehand A, Langella P, Rautonen N, Sansonetti PJ, Burcelin R: Intestinal mucosal adherence and translocation of commensal bacteria at the early onset of type 2 diabetes: molecular mechanisms and probiotic treatment. EMBO Mol Med 2011, 3:559-572.

35. Amar J, Serino M, Lange C, Chabo C, lacovoni J, Mondot S, Lepage P, Klopp C, Mariette J, Bouchez O, Perez L, Courtney M, Marre M, Klopp P, Lantieri O, Doré J, Charles M, Balkau B, Burcelin R, D.E.S.I.R. Study Group: Involvement of tissue bacteria in the onset of diabetes in humans: evidence for a concept. Diabetologia 2011, 54:3055-3061.

36. Medzhitov R: Origin and physiological roles of inflammation. Nature 2008, 454:428-435.

37. Hirabara SM, Gorjão R, Vinolo MA, Rodrigues AC, Nachbar RT, Curi R: Molecular targets related to inflammation and insulin resistance and potential interventions. J Biomed Biotechnol 2012, 2012:1-16.

38. Cristofaro P, Opal SM: Role of Toll-like receptors in infection and immunity: clinical implications. Drugs 2006, 66:15-29.

39. Kumar H, Kawai T, Akira S: Toll-like receptors and innate immunity. Biochem Biophys Res Commun 2009, 388:621-625.

40. Drewe J, Beglinger C, Fricker G: Effect of ischemia on intestinal permeability of lipopolysaccharides. Eur J Clin Invest 2001, 31:138-144.

41. Neal MD, Leaphart C, Levy R, Prince J, Billiar TR, Watkins S, Li J, Cetin S, Ford H, Schreiber A, Hackam DJ: Enterocyte TLR4 mediates phagocytosis and translocation of bacteria across the intestinal barrier. J Immunol 2006, 176:3070-3079.

42. Spruss A, Kanuri G, Wagnerberger S, Haub S, Bischoff SC, Bergheim I: Toll-like receptor 4 is involved in the development of fructose-induced hepatic steatosis in mice. Hepatology 2009, 50:1094-1104.

43. Cani PD, Delzenne NM: Gut microflora as a target for energy and metabolic homeostasis. Curr Opin Clin Nutr Metab Care 2007, 10:729-734.

44. Akashi-Takamura S, Miyake K: TLR accessory molecules. Curr Opin Immunol 2008, 20:420-425.

45. Sugita H, Kaneki M, Tokunaga E, Sugita M, Koike C, Yasuhara S, Tompkins RG, Martyn JA: Inducible nitric oxide synthase plays a role in LPS-induced hyperglycemia and insulin resistance. Am J Physiol 2002, 282:E386-E394.

46. Stamler JS, Toone EJ, Lipton SA, Sucher NJ: (S)NO signals: translocation, regulation, and a consensus motif. Neuron 1997, 18:691-696.

47. Shinozaki S, Choi CS, Shimizu N, Yamada M, Kim M, Zhang T, Shiota G, Dong HH, Kim YB, Kaneki M: Liver-specific inducible nitric-oxide synthase expression is sufficient to cause hepatic insulin resistance and mild hyperglycemia in mice. J Biol Chem 2011, 286:34959-34975. 
48. Ovadia H, Haim Y, Nov O, Almog O, Kovsan J, Bashan N, Benhar M, Rudich A: Increased adipocyte S-nitrosylation targets anti-lipolytic action of insulin: relevance to adipose tissue dysfunction in obesity. J Biol Chem 2011 286:30433-30443.

49. Kim JJ, Sears DD: TLR4 and Insulin Resistance. Gastroenterol Res Pract 2010, 2010:212563-212574.

50. Konner A, Bruning J: Toll-like receptors: linking inflammation to metabolism. Trends Endocrinol Metab 2011, 22:16-23.

51. Hiratani K, Haruta T, Tani A, Kawahara J, Usui I, Kobayashi M: Roles of mTOR and JNK in serine phosphorylation, translocation, and degradation of IRS-1. Biochem Biophys Res Commun 2005, 335:836-842.

52. Saltiel $A R$, Kahn CR: Insulin signalling and the regulation of glucose and lipid metabolism. Nature 2001, 414:799-806.

53. Bluestone JA, Herold K, Eisenbarth G: Genetics, pathogenesis and clinical interventions in type 1 diabetes. Nature 2010, 464:1293-1300.

54. Dabelea DRA, Bell RB, D'Agostino J, Bell RA, D'Agostino RB Jr, Imperatore G, Johansen JM, Linder B, Liu LL, Loots B, Marcovina S, Mayer-Davis EJ, Pettitt DJ, Waitzfelder B: Incidence of diabetes in youth in the United States. JAMA 2007, 297:2716-2724.

55. Chervonsky AV: Influence of microbial environment on autoimmunity. Nat Immunol 2010, 11:28-35.

56. Anderson MS, Bluestone JA: The NOD mouse: a model of immune dysregulation. Annu Rev Immunol 2005, 23:447-485.

57. Ohland CL, Macnaughton WK: Probiotic bacteria and intestinal epithelial barrier function. Am J Physiol Gastrointest Liver Physiol 2010, 298:G807-G819.

58. Atkinson MA, Chervonsky A: Does the gut microbiota have a role in type 1 diabetes? Early evidence from humans and animal models of the disease. Diabetologia 2012, 55:2868-28677.

59. Vehik K, Dabelea D: The changing epidemiology of type 1 diabetes: why is it going through the roof? Diabetes Metab Res Rev 2011, 27:3-13.

60. Neu J, Reverte CM, Mackey AD, Liboni K, Tuhacek-Tenace LM, Hatch M, Li N, Caicedo RA, Schatz DA, Atkinson M: Changes in intestinal morphology and permeability in the biobreeding rat before the onset of type 1 diabetes. J Pediatr Gastroenterol Nutr 2005, 40:589-595.

61. Lam YY, Ha CWY, Campbell CR, Mitchell AJ, Dinudom A, Oscarsson J, Cook DI, Hunt NH, Caterson ID, Holmes AJ, Storlien LH: Increased Gut Permeability and Microbiota Change Associate with Mesenteric Fat Inflammation and Metabolic Dysfunction in Diet-Induced Obese Mice. Plos One 2012, 7:34233.

62. Neu J, Lorca G, Kingma SDK, Triplett EW: The Intestinal Microbiome: Relationship to Type 1. Diabetes 2010, 39:563-571.

63. Tiittanen M, Huupponen JT, Knip M, Vaarala O: Insulin treatment in patients with type 1 diabetes induces upregulation of regulatory T-cell markers in peripheral blood mononuclear cells stimulated with insulin in vitro. Diabetes 2006, 55:3446-3454.

64. Vaarala O, Atkinson M, Neu J: The "perfect storm" for type 1 diabetes: the complex interplay between intestinal microbiota, gut permeability, and mucosal immunity. Diabetes 2008, 57:2555-2562.

65. Vaarala $O$, Knip M, Paronen J, Hämäläinen AM, Muona P, Väätäinen M, Ilonen J, Simell O, Akerblom HK: Cow's milk formula feeding induces primary immunization to insulin in infants at genetic risk for type 1 diabetes. Diabetes 1999, 48:1389-1394.

66. Proal AD, Albert PJ, Marshall T: Autoimmune disease in the era of the metagenome. Autoimmun Rev 2009, 8:677-681.

67. Murri M, Leiva I, Gomez-Zumaquero JM, Tinahones FJ, Cardona F, Soriguer F, Queipo-Ortuño Ml: Gut microbiota in children with type 1 diabetes differs from that in healthy children: a case-control study. BMC Med 2013, 11:46.

68. Goffau M, Luopajärvi K, Knip M, Ilonen J, Ruohtula T, Härkönen T, Orivuori L, Hakala S, Welling GW, Harmsen HJ, Vaarala O: Fecal microbiota composition differs between children with beta-cell autoimmunity and those without. Diabetes 2013, 62:1238-1244

69. Bosi E, Molteni L, Radaelli MG, Fermo I, Bazzigaluppi E, Piemonti L, Pastore $M R$, Paroni R: Increased intestinal permeability precedes clinical onset of type 1 diabetes. Diabetologia 2006, 49:2824-2827.

70. Brugman S, Klatter FA, Visser JT, Wildeboer-Veloo AC, Harmsen HJ, Rozing J, Bos NA: Antibiotic treatment partially protects against type 1 diabetes in the bio-breeding diabetes-prone rat. Is the gut flora involved in the development of type 1 diabetes? Diabetologia 2006, 49:2105-2108.

71. Roesch LFW, Lorca GL, Casella G, Wildeboer-Veloo AC, Harmsen HJ, Rozing J, Bos NA: Culture-independent identification of gut bacteria correlated with the onset of diabetes in a rat model. Isme J 2009, 3:536-548.
72. Cerf-Bensussan N, Gaboriau-Routhiau V: The immune system and the gut microbiota: friends or foes? Nat Rev Immunol 2010, 10:735-744.

73. Giongo A, Gano KA, Crabb DB, Mukherjee N, Novelo LL, Casella G, Drew JC, Ilonen J, Knip M, Hyöty H, Veijola R, Simell T, Simell O, Neu J, Wasserfall CH, Schatz D, Atkinson MA, Triplett EW: Toward defining the autoimmune microbiome for type 1 diabetes. ISME J 2011, 5:82-91.

74. Brown CT, Davis-Richardson AG, Giongo A, Mukherjee N, Novelo LL, Casella G, Drew JC, llonen J, Knip M, Hyöty H, Veijola R, Simell T, Simell O, Neu J, Wasserfall $\mathrm{CH}$, Schatz D, Atkinson MA, Triplett EW: Gut microbiome metagenomics analysis suggests a functional model for the development of autoimmunity for type 1 diabetes. Plos One 2011, 6:e25792.

75. Louis P, Flint HJ: Diversity, metabolism and microbial ecology of butyrate-producing bacteria from the human large intestine. Fems Microbiology Letters 2009, 294:1-8.

76. Lewis K, Lutgendorff F, Phan V, Söderholm JD, Sherman PM, McKay DM: Enhanced Translocation of Bacteria Across Metabolically Stressed Epithelia is Reduced by Butyrate. Inflammatory Bowel Diseases 2010, 16:1138-1148

77. Paassen BN, Vincent A, Puiman PJ, van der Sluis M, Bouma J, Boehm G, van Goudoever JB, van Seuningen I, Renes IB: The regulation of intestinal mucin MUC2 expression by short-chain fatty acids: implications for epithelial protection. Biochem J 2009, 420:211-219.

78. Wen L, Ley RE, Volchkov PY, Avanesyan L, Stonebraker AC, Hu C, Wong FS, Szot GL, Bluestone JA, Gordon Jl, Chervonsky AV: Innate immunity and intestinal microbiota in the development of type 1 diabetes. Nature 2008, 455:1109-1113.

79. Hara N, Alkanani AK, Ir D, Robertson CE, Wagner BD, Frank DN, Zipris D: Prevention of virus-induced type 1 diabetes with antibiotic therapy. $\mathrm{J}$ Immunol 2012, 15:3805-3814.

80. Thomas HE, McKenzie MD, Angstetra E, Campbell PD, Kay TW: Beta cell apoptosis in diabetes. Apoptosis 2009, 14:1389-1404.

81. Seewaldt S, Thomas HE, Ejrnaes M, Christen U, Wolfe T, Rodrigo E, Coon B, Michelsen B, Kay TW, von Herrath MG: Virus-induced autoimmune diabetes: most beta-cells die through inflammatory cytokines and not perforin from autoreactive (anti-viral) cytotoxic T-lymphocytes. Diabetes 2000, 49:1801-1809.

82. Foulis AK, Farquharson MA, Hardman R: Aberrant expression of class II major histocompatibility complex molecules by B cells and hyperexpression of class I major histocompatibility complex molecules by insulin containing islets in type 1 (insulin-dependent) diabetes mellitus. Diabetologia 1987, 30:333-343.

83. Itoh N, Hanafusa T, Miyazaki A, Miyagawa J, Yamagata K, Yamamoto K, Wagur M, Imagawa A, Tamura S, Inada M, Kawata S, Tarui S, Kono N, Matsuzawa Y: Mononuclear cell infiltration and its relation to the expression of major histocompatibility complex antigens and adhesion molecules in pancreas biopsy specimens from newly diagnosed insulin-dependent diabetes mellitus patients. J Clin Invest 1993, 92:2313-2322.

84. Round JL, Mazmanian SK: Inducible Foxp3+ regulatory T-cell development by a commensal bacterium of the intestinal microbiota. Proc Natl Acad Sci 2010, 107:12204-12209.

85. Serreze DV, Post CM, Chapman HD, Johnson EA, Lu B, Rothman PB: Interferon-gamma receptor signaling is dispensable in the development of autoimmune type 1 diabetes in NOD mice. Diabetes 2000, 49:2007-2011.

86. Geuking MB, Cahen zli J, Lawson MA: Intestinal bacterial colonization induces mutualistic regulatory T cell responses. Immunity 2011, 34:794-806.

87. Kriegel MA, Sefik E, Hill JA, Wu HJ, Benoist C, Mathis D: Naturally transmitted segmented filamentous bacteria segregate with diabetes protection in nonobese diabetic mice. Proc Natl Acad 2011, 108:11548-11553.

88. Mazmanian SK, Round JL, Kasper DL: A microbial symbiosis fact or prevents intestinal inflammatory disease. Nature 2008, 453:620-625.

89. Rook GA, Brunet LR: Microbes, immunoregulation, and the gut. Gut 2005 54:317-320.

90. WHO - World Health Organization: Evaluation of Health and Nutritional Properties of Probiotics in Food Including Powder Milk with Live Lactic Acid Bacteria, Joint WHO/FAO Expert Consultation on Geneva. Cordoba, Argentina: WHO; 2001.

91. Gill H, Prasad J: Probiotics, immunomodulation, and health benefits. Adv Exp Med Bio 2008, 606:423-454.

92. Prasad J, Gill HS, Smart JB, Gopal PK: Selection and characterization of Lactobacillus and Bifidobacterium strains for use as probiotics. Int Dairy J 1998, 8:993-1002. 
93. Hummel S, Veltman K, Cichon C, Sonnenborn U, Schmidt MA: Differential Targeting of the E-Cadherin/ $\beta$-Catenin Complex by Gram-Positive Probiotic Lactobacilli Improves Epithelial Barrier Function. App/ Environ Microbiol 2012, 78:1140-1147.

94. Singh R, Lei P, Andreadis ST: PKC- $\delta$ binds to E-cadherin and mediates EGF-induced cell scattering. Exp Cell Res 2009, 315:2899-2913.

95. Gooding JM, Yap KL, Ikura M: The cadherin-catenin complex as a focal point of cell adhesion and signalling: new insights from three-dimensional structures. BioEssays 2004, 26:497-511.

96. Kingma SDK, Li N, Sun F, Valladares RB, Neu J, Lorca GL: Lactobacillus johnsonii N6.2 Stimulates the Innate Immune Response through Toll-Like Receptor 9 in Caco-2 Cells and Increases Intestinal Crypt Paneth Cell Number in BioBreeding Diabetes-Prone Rats. J Nutr 2011, 141:1023-1028.

97. Jabri B, Ebert E: Human CD8+ intraepithelial lymphocytes: a unique model to study the regulation of effector cytotoxic T lymphocytes in tissue. Immunol Rev 2007, 215:202-214.

98. Valladares R, Sankar D, Li N, Williams E, Lai KK, Abdelgeliel AS, Gonzalez CF, Wasserfall CH, Larkin J, Schatz D, Atkinson MA, Triplett EW, Neu J, Lorca GL: Lactobacillus johnsonii N6.2 Mitigates the Development of Type 1 Diabetes in BB-DP Rats. Plos One 2010, 5:e10507.

99. Lau K, Benitez P, Ardissone A, Wilson TD, Collins EL, Lorca G, Li N, Sankar D, Wasserfall C, Neu J, Atkinson MA, Shatz D, Triplett EW, Larkin J: Inhibition of Type 1 Diabetes Correlated to a Lactobacillus johnsonii N6.2-Mediated Th17 Bias. J Immunol 2011, 186:3538-3546.

100. Ivanov II, Frutos Rde L, Manel N, Yoshinaga K, Rifkin DB, Sartor RB, Finlay BB, Littman DR: Specific microbiota direct the differentiation of IL-17-producing T-helper cells in the mucosa of the small intestine. Cell Host Microbe 2008, 4:337-349.

101. Martin-Orozco N, Chung Y, Chang SH, Wang YH, Dong C: Th17 cells promote pancreatic inflammation but only induce diabetes efficiently in lymphopenic hosts after conversion into Th1 cells. Eur J Immunol 2009, 39:216-224.

102. Yadav H, Jain S, Sinha PR: Antidiabetic effect of probiotic dahi containing Lactobacillus acidophilus and Lactobacillus casei in high fructose fed rats. Nutrition 2007, 23:62-68.

103. Andersson U, Bränning C, Ahrné S, Molin G, Alenfall J, Onning G, Nyman M, Holm C: Probiotics lower plasma glucose in the high-fat fed C57BL/6J mouse. Benef Microbes 2010, 1:189-196.

104. Mencarelli A, Cipriani S, Renga B, Bruno A, D'Amore C, Distrutti E, Fiorucci S: VSL\#3 Resets Insulin Signaling and Protects against NASH and Atherosclerosis in a Model of Genetic Dyslipidemia and Intestinal Inflammation. Plos One 2012, 7:e45425.

105. Ma X, Hua J, Li Z: Probiotics improve high fat diet-induced hepatic steatosis and insulin resistance by increasing hepatic NKT cells. $J$ Hepatol 2008, 49:821-830.

106. Calcinaro F, Dionisi S, Marinaro M, Candeloro P, Bonato V, Marzotti S, Corneli RB, Ferretti E, Gulino A, Grasso F, De Simone C, Di Mario U, Falorni A, Boirivant M, Dotta F: Oral probiotic administration induces interleukin-10 production and prevents spontaneous autoimmune diabetes in the non-obese diabetic mouse. Diabetologia 2005, 48:1565-1575.

107. Moore KW, de Waal MR, Coffman RL, O'Garra A: Interleukin-10 and the interleukin-10 receptor. Annu Rev Immunol 2001, 19:683-765.

108. Ohkawara S, Furuya H, Nagashima K, Asanuma N, Hino T: Oral administration of butyrivibrio fibrisolvens, a butyrate-producing bacterium, decreases the formation of aberrant crypt foci in the colon and rectum of mice. $J$ Nutr 2005, 135:2878-2883.

109. Yadav H, Jain S, Sinha PR: The Effect of Probiotic Dahi Containing Lactobacillus acidophilus and Lactobacillus casei on Gastropathic Consequences in Diabetic Rats. J Med Food 2008, 11:62-68.

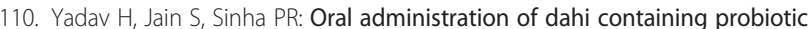
Lactobacillus acidophilus and Lactobacillus casei delayed the progression of streptozotocin-induced diabetes in rats. J Dairy Res 2008, 75:189-195.

111. Lu YC, Yin LT, Chang WT, Huang JS: Effect of Lactobacillus reuteri GMNL-263 treatment on renal fibrosis in diabetic rats. J Biosci Bioeng 2010, 110:709-715.

112. Chen J, Wang R, Li XF, Wang RL: Bifidobacterium adolescentis supplementation ameliorates visceral fat accumulation and insulin sensitivity in an experimental model of the metabolic syndrome. $\mathrm{Br} \mathrm{J}$ Nutr 2012, 10:1429-1434

113. Drucker DJ: Glucagon-like peptides: regulators of cell proliferation, differentiation, and apoptosis. Mol Endocrinol Rev 2003, 17:161-171.
114. Lee SK, Yang KM, Cheon JH, Kim TI, Kim WH: Anti-inflammatory mechanism of Lactobacillus rhamnosus GG in lipopolysaccharide- stimulated HT-29 cell. Korean J Gastroenterol 2012, 60:86-93.

115. Cani PD, Delzenne NM: The role of the gut microbiota in energy metabolism and metabolic disease. Curr Pharm Des 2009, 15:1546-1558.

116. Marik E: Colonic flora, Probiotics, Obesity and Diabetes. Front Endocrinol 2012, 3:87

117. Luoto R, Laitinen K, Nermes M, Isolauri E: Impact of maternal probiotic-supplemented dietary counselling on pregnancy outcome and prenatal and postnatal growth: a double-blind, placebo-controlled study. Br J Nutr 2010, 103:1792-1799.

118. Laitinen K, Poussa T, Isolauri E: Probiotics and dietary counselling contribute to glucose regulation during and after pregnancy: a randomised controlled trial. Br J Nutr 2009, 101:1679-1687.

119. Karczewski J, Troost FJ, Konings I, Dekker J, Kleerebezem M, Brummer RJ Wells JM: Regulation of human epithelial tight junction proteins by Lactobacillus plantarum in vivo and protective effects on the epithelial barrier. Am J Physiol Gastrointest Liver Physiol 2010, 298:G851-G859.

120. Walsh-Reitz MM, Huang EF, Musch MW, Chang EB, Martin TE, Kartha S, Toback FG: AMP-18 protects barrier function of colonic epithelial cells: role of tight junction proteins. Am J Physiol Gastrointest Liver Physiol 2005, 289:G163-G171.

121. Mikelsaar M, Zilmer M: Lactobacillus fermentum ME-3-an antimicrobial and antioxidative probiotic. Microb Ecol Health Dis 2009, 21:1-27.

doi:10.1186/1475-2891-13-60

Cite this article as: Gomes et al:: Gut microbiota, probiotics and diabetes. Nutrition Journal 2014 13:60.

\section{Submit your next manuscript to BioMed Central and take full advantage of:}

- Convenient online submission

- Thorough peer review

- No space constraints or color figure charges

- Immediate publication on acceptance

- Inclusion in PubMed, CAS, Scopus and Google Scholar

- Research which is freely available for redistribution 